\title{
INDIKATORJI O OKOLJU IN RAZVOJU KOT POMOČ ODLOČITVAM ZA NADALJNII URAVNOTEŽEN REGIONALNO-PROSTORSKI RAZVOJ
}

Povečana pozornost okoljskim vprašanjem se odraža tudi v razvojnih politikah in programih, pri njihovem spremljanju pa imajo pomembno vlogo različni okoljski kazalniki. Z njihovo pomočjo je mogoče meriti okoljske vplive in učinke relevantnih programov, ukrepov in projektov ter na ta način ugotavljati njihovo okoljsko sprejemljivost ter usklajenost s cilji s področja varstva okolja, s tem pa tudi prispevati k trajnostnemu razvoju območij, kjer se odvijajo programi. Okoljski kazalniki so bili tudi v središču zanimanja projekta Indikatorji o okolju in razvoju kot pomoč odločitvam za nadaljnji uravnotežen regionalno-prostorski razvoj, ki je potekal v letih 2002-2004 v okviru Ciljnega raziskovalnega programa "Konkurenčnost Slovenije 2001-2006". Odgovorni nosilec projekta je bila Metka Špes, pri delu pa so sodelovali še Dejan Cigale, Barbara Lampič, Dušan Plut in Ana Vovk Korže. Projekt sta sofinancirala Agencija RS za regionalni razvoj in Ministrstvo za šolstvo, znanost in šport.

Pri projektu v izhodišče ni bil postavljen specifičen raziskovalni problem, ki bi ga bilo treba razrešiti s pomočjo ustrezne metodologije, temveč so bili cilji projekta prvenstveno aplikativne narave. Namen projekta je bil ponuditi predlog nabora okoljskih kazalnikov spremljanja razvoja za državno in regionalno raven. Pri tem je šlo predvsem za oblikovanje naborov (možnih) kazalnikov, ki bi jih bilo mogoče uporabiti za spremljanje programov in projektov.

V okviru dela na projektu je bilo tako med drugim pripravljenih več naborov okoljskih kazalnikov, pri čemer so bili najbolj podrobno obravnavani kontekstni kazalniki. Pri tem smo upoštevali obstoječe domače in tuje definicije. Posebej smo opozorili na s tem povezane vsebinske nejasnosti in pomisleke. Kot dovolj pomemben se je izkazal problem neusklajenosti definicij ter velikega števila vsebinsko sorodnih kazalnikov. Naš namen je bil predstaviti dobre in slabe strani uporabljenih kazalnikov ter njihovo vsebinsko utemeljenost oziroma relevantnost, ki je pogojena tudi $\mathrm{z}$ mednarodnimi zahtevami ter stanjem okolja $\mathrm{v}$ Sloveniji. Posebno pozornost smo namenjali virom podatkov ter metodologiji, potrebni za izračun kazalnikov.

Cilj projekta Indikatorji o okolju in razvoju kot pomoč odločitvam za nadaljnji uravnotežen regionalno-prostorski razvoj je bilo oblikovanje nabora okoljskih kazalnikov, ki pa predstavljajo le del bistveno večjega sistema spremljanja in vrednotenja programov in projektov. Sami po sebi imajo le omejeno uporabno vrednost, zato je pomembno, da so vključeni v logičen in funkcionalen sistem kazalnikov oziroma sistem vrednotenja in spremljanja nasploh. Le tako lahko zares služijo svojemu namenu.

Dejan Cigale 